International Journal of Engineering \& Technology, $7(2.5)(2018) 4-8$
International Journal of Engineering \& Technology
SPC
Website: www.sciencepubco.com/index.php/IJET
Research Paper

\title{
Fostering telecommunication industry development through collaboration among university, industry, and government Elevating triple helix model of collaboration in Indonesia
}

\author{
Mingchang Wu ${ }^{1}$, Ibnu Siswanto ${ }^{2 *}$, Zainal Arifin ${ }^{3}$ \\ ${ }^{1}$ Graduate School of Vocational and Technical Education, National Yunlin University of Science and Technology, Taiwan \\ ${ }^{2}$ Graduate School of Vocational and Technical Education, National Yunlin University of Science and Technology, \\ Taiwan and Yogyakarta State University, Indonesia \\ ${ }^{3}$ Faculty of Engineering, Yogyakarta State University, Indonesia \\ *Corresponding author E-mail: ibnusiswanto@uny.ac.id
}

\begin{abstract}
Background and objective: Over the past decade, Indonesian telecommunication market has enjoyed a steady growth by over than $30 \%$ per year. However, all of the cellphone and smartphone companies are foreign company and there is no local company. Therefore, this paper purports to analyze the current telecommunication industry development in Indonesia and how to elevate it for further enhancement.

Materials and Methods: This article firstly reviewed the theory of triple helix model type of collaboration among university, industry, and government. Secondly, analyzed how to elevate it in order to foster Indonesian telecommunication industry. Finally, it gives some suggestions for further triple helix model implementation in Indonesia.

Results: The steps to implement triple helix model of collaboration in Indonesia are (1) improving facilities and quality of the academic research, developing a collaboration that focuses on the applied science transfer, developing a product that is appropriate to the market needs, and (2) developing new hardware and software business spin-off. During the trilateral collaboration, evaluation is continuously based on some indicators, such as the number of patents, customer satisfaction with the products, and the number of new business units. Conclusions: The triple helix model of innovation has become salient in the development of Indonesian telecommunication industry. Readiness of Indonesia to implement knowledge-based economy development needs to be improved through human resource development, research facility enhancement, and by encouraging industry and governments' participation in basic research and education.
\end{abstract}

Keywords: Government, Industry, Telecommunication Industry, Triple helix, University

\section{Introduction}

According to Global Media Intelligence Report [1] in 2015, there were 55 million Indonesian smartphone users and this number will keep growing by $37.1 \%$ annually. It was also estimated that the number of Indonesian smartphone users will reach 65.2, 74.9, and 83.5 million in 2016, 2017, and 2018, respectively. An enormous number of consumers encouraged so many mobile phone manufacturers to target Indonesian market. Three major mobile phone manufacturers operating in Indonesia are Samsung, OPPO, and ASUS. All of them are multinational companies and there are no local manufacturers which are ready to take the opportunity of this potential market.

According to the regulation of Ministry of Industry of Republic Indonesia No 68 Year 2015, government's strategies to develop the telecommunication industry are (1) encouraging mobile phone manufacturers to build their factories in Indonesia, (2) increasing the local content of hardware and software by at least 30\%, (3) charging tax $5-15 \%$ for the imported components.

Government regulations that support the development of telecommunication industry should be followed by the collaboration among government, industry, and university to optimize all resources. Experience of the developed countries in developing science-based industry by optimizing the cooperation among three sectors, namely Samsung in South Korea, Asus in Taiwan, Silicon Valley industrial area in the United States, and vaccines industry in Canada can be adopted in Indonesia. This paper aims to review the triple helix model of collaboration theory and how to implement it to foster the development of Indonesian telecommunication industry.

\section{Method}

This article firstly reviewed the theory of triple helix model type of collaboration among university, industry, and government. This theory was first published in the 1990s by Etzkowitz and Leydesdorff. Secondly, this article analyzed the current development of Indonesian telecommunication industry based on the indicators of collaboration between university, government, and industry. Finally, it gives some suggestions for further triple helix model implementation, especially on telecommunication industry development in Indonesia.

\subsection{Triple helix theory for interdisciplinary collabora- tion}




\subsubsection{The definitions of triple helix theory}

The triple helix is a model of relationship among government, industry, and university to capitalize knowledge in order to pursue new knowledge, innovation, and economic development [2, 3, 4]. This model is inherently rooted in the increasingly important role of university in the transition from an industrial economy to a knowledge-based economy [5]. In the knowledge-based society, there is a changing relation among university, industry, and government from one-way knowledge transfer to an interactive model of knowledge transfer among institutions which contribute to the ongoing innovative processes of creation, acquisition, and transfer [6]. Innovation is understood as a subsequent outcome from a multifarious and dynamic process in the relation among science, technology, research and development of three sectors in a spiral of endless transitions [7]. The triple helix represents not only the multiple reciprocal relationships among university, industry, and government, but also the internal transformation within three institutions [7]. These activities create an intersection where the actors can partially substitute and take others' role and/or generate new institutional formats $[8,9]$. For instance, the university takes a part of the industrial role to creating small innovative companies, industry partially takes university's role to conduct their own research and training centers, and government might become a venture capitalist through some incentive programs [7, 8]. Moreover, new organization arises from the intersection among three elements like new firms, science parks, inter-university research centers, and the networked universities [10].

The triple helix process of knowledge capitalization consists of three phases [7]. The first phase of the triple helix model is an internal transformation of each institution, such as the development of strategic cooperation among companies or an alliance by universities. The second phase is influence of one sphere upon another. Furthermore, third phase is formation of new trilateral joint networks and organizations from the interaction among three helices. The newly formed institution comes up with new ideas and formats to generate high-tech-based economy development [7].

Synthetically, it can be concluded that triple helix model is a dynamic interaction among public sectors, private sectors, and academia to generate and commercialize new innovative products through the development of new institutions/firms in order to pursue knowledge-based economic growth. Their interactions may go through four stages. First, the internal environment of each institutional sphere is transformed into a better condition. Second, the sectors exert influence on one another. Third, an organization is created based on the overlapping relationship among university, industry, and government. Lastly, an entrepreneurial dynamic is formed through seamless interactions within and among three sectors.

\subsubsection{The functions of triple helix model}

The main function of Triple Helix model is to generate, diffuse, utilize, and commercialize knowledge and innovation [4]. It might be in form of a science park, business incubator, joint research, new firm, business incubator, or knowledge transfers [10].

Another function of Triple Helix model is to create an innovative regional area. There are three steps to realize this goal, namely knowledge space, consensus space, and innovation space [7]. The first step is the creation of "knowledge space" or concentration of related R\&D activities in a local area. The existence of such "reticulated" agglomerations has been identified as a precursor to knowledge-based regional economic development [11]. It underlies the development of research projects and new technologyrelated businesses in areas of the society which had not previously had this potency. Moreover, the second stage is "consensus space", a venue that brings together people from university, government, and industry to generate new strategies and ideas. The Consensus space encompasses the activities that bring together three institutions to discuss and evaluate proposals, exchange resources, and promote joint projects [12]. Lastly, the third stage is "innovation space", a new organizational mechanism that attempts to realize the goals articulated in the consensus space [7]. Innovation space comprehends activities of the individuals and hybrid organizations towards the development of new innovative firms [12]. Moreover, this area attracts the innovative talents and intellectual potency from elsewhere, enhancing the competitiveness of region and country. The formation of these Spaces is conceptualized as the result of the interaction among university, industry and government spheres. Once the spaces are formed, they interact with each other in a continuous transition that occurs in different directions as a nonlinear process [12].

Synthetically, it can be concluded that the function of triple helix is to create, diffuse, utilize, and commercialize knowledge and innovation through the creation of innovative environments.

\subsubsection{The relationship among triple helix components}

The relationship among university, industry, and government in the triple helix model includes technology transfer or acquisition, collaboration and conflict moderation, collaborative leadership, substitution and networking [9]. These relationships reflect the inducing change, evolutionary social and economic mechanisms at work in Triple Helix interactions [12].

Technology transfer is an important activity in the triple helix model in which the university increasingly produces and transfers new innovative technology to other institutions [9]. Furthermore, collaboration and conflict moderation are dynamic relationships arising in the changing nature of work, workplace, and organizations among three sectors and their personals [9]. Moreover, collaborative leadership is an integral part of collaboration and conflict moderation capacity. The leader plays a key role in order to bridge gaps, generate consensus and balance conflict of interest, and integrate skills among components of triple helix [9].

Additionally, substitution is the type of interactions when another component in the triple helix is weak and needs to be supported or replaced9. For instance, the industry takes the role of university in generating proprietary education for the society (e.g. Pixar University, Apple University, and Cisco networking academy). Another type of the dynamic relationship among three sectors is networking. Networking is the middle way between the loose coupling of markets interactions and the tight relationships of hierarchical structures [9].

\subsubsection{The role of government, industry and university in the triple helix model}

Triple helix model enforces the contribution of university, government, and industry in their trilateral interactions. In addition to cooperation among three institutions, they have to maintain their primary function to produce maximum output. The role of government is to be responsible for policies, laws, and information network [10]. Moreover, the government acts to increase investment in basic research, strengthen its financial aid for education, and invest in products commercialization [13]. The government also functions to enhance cooperation between the demand for knowledge and innovation (industry) and the supply of knowledge and innovation (universities), and provide an excellent location for the new innovative area development [14].

Furthermore, the university plays its role to provide human resource, scientific finding, technology inventions, and business spin-offs/starts-up [10]. The university should take the role to standardize terms in the sponsored research and patent application, share research facilities for others, recruit top-notch entrepreneurs to inspire their students in starting a business, and provide product commercialization opportunities for the post-doctoral researchers [13]. Moreover, in the Triple Helix concept, universities are expected to keep enhancing their knowledge, so it will meet the need of local industry [14].

Afterward, industry acts to manage goods, tax, R\&D investment, and venture capital [10]. The industry also acts to invest in early stage funds, gives suggestions on industrial needs, and joint indus- 
try consortia [13]. Moreover, in the Triple Helix concept, the industry has a role in demanding knowledge, innovation, and skillful people, and contributing to education in the universities, by providing fund, lecturers, or internships [14].

Synthetically, it can be concluded that government is responsible for policies, laws, information network, increasing investment in basic research, providing financial aid for education, product commercialization, and providing an excellent location for the innovative area development. The university acts to provide human resource, scientific finding, technology inventions, and business spin-off/start-up, share research facilities, and conduct research that is needed by the local industry. Moreover, the industry plays a role in managing goods, tax, and R\&D investment, investing in the early stage of research, providing the information of industry needs, and supporting educational system at university.

\section{Results}

\subsection{Framework of implementing triple helix for tele- communication industry in Indonesia}

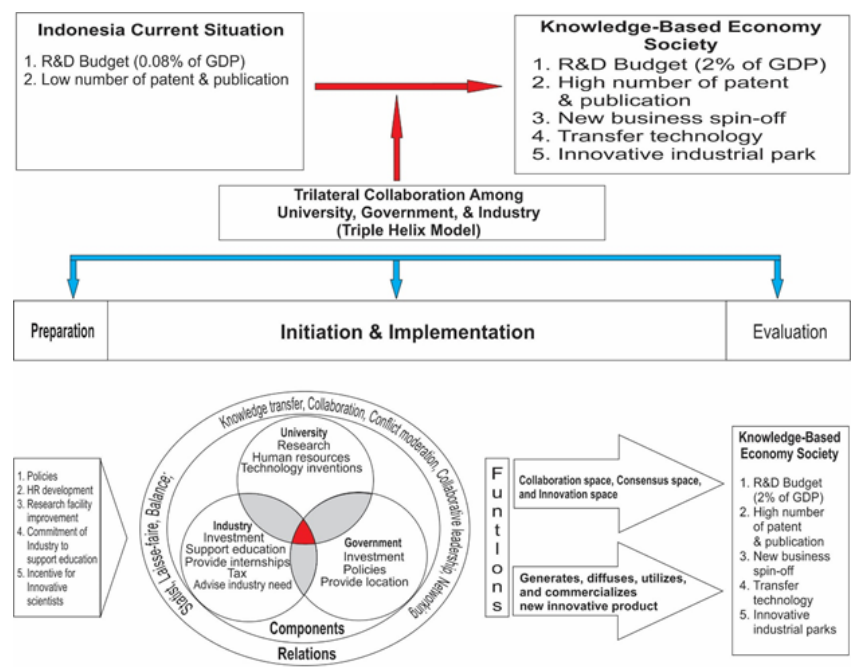

Fig. 1: Implementing triple helix for telecommunication industry development in Indonesia

\subsubsection{Preparation (Identifying and motivating the relevant stakeholders)}

Table 1: Analysis of current situation in three institutions

\begin{tabular}{|c|c|}
\hline Stakeholders & Analysis \\
\hline Government & $\begin{array}{l}\text { Policies to support the telecommunication industry } \\
\text { development are 1) Regulation of Trade Minister No. } \\
82 \text { Year } 2012 \text { concerning the provision of imported } \\
\text { mobile phones, handheld computers, and tablets; 2) } \\
\text { Regulation of Trade Minister No. } 69 \text { Year } 2014 \text { on the } \\
\text { procedures for calculating the value of domestic com- } \\
\text { ponent level electronic and telematic industry; 3) } \\
\text { Regulation of Ministry of Communication and Infor- } \\
\text { matics No. } 27 \text { Year } 2015 \text { concerning the technical } \\
\text { requirements of the equipment and/or LTE technology } \\
\text { based on telecommunication equipment standard (DCL } \\
\text { at least } 30 \% \text { ) on } 1 \text { January } 2017 \\
\text { The budget allocation for research and development is } \\
0.08 \% \text { of GDP (Minimum } 2 \% \text { of GDP) }\end{array}$ \\
\hline & $\begin{array}{l}\text { There is a long duration for the patent processing ( } 3 \text { to } \\
6 \text { years) }\end{array}$ \\
\hline Industry & $\begin{array}{l}\text { There are } 16 \text { telecommunication industries } \\
\text { Almost all industries are the trading or product- } \\
\text { assembling companies from other countries } \\
\text { There is no telecommunication industry to propose } \\
\text { patents }\end{array}$ \\
\hline University & $\begin{array}{l}\text { Research quality ( } 57 \text { th rank of } 239 \text { countries on inter- } \\
\text { national scientific publication in Schimagojr) }\end{array}$ \\
\hline
\end{tabular}

Number of Patents: 1) 11 patents in World Intellectual Property Organization (2013); 2) 8,023 patents in Indonesia (2014), only $10 \%$ filed by the citizens of Indonesia.

The current situation in three institutions might be development reviewed and analyzed through some indicators in the preparation stage. Readiness of government is measured through policies and laws which support the telecommunication industry, budget allocation for the research and development, and patent application. Number and activity in the telecommunication industry are measured through analysis. Moreover, the university is measured particularly through its human resources capability on research and laboratories facility.

Government support on telecommunication industry development (Table 1) shows that there are some policies and regulations to force the companies in building their factories in Indonesia and increasing the local content for each product. Forcing the industry to build its facilities in Indonesia will create more job opportunity for the youngster and local content enhancement will stimulate the research and development activities of the academia and creation of new start-off business. Moreover, readiness of industry (Table 1 ) is analyzed through its trading and manufacturing on telecommunication products, including hardware and software. When more products are created, manufactured, and assembled in Indonesia, telecommunication industry development is also improved. In addition, capability of university to drive the collaboration is mainly measured through its research activities, the number of researchers who are able to conduct high-quality research and publish it in the international journal, and on its research facilities. The data (Table 1) shows that Indonesian researcher needs to improve its research activity and quality based on the number of international publication (57th rank of 293 countries) and patent application (11 patent applications in 2013).

\subsubsection{Initiation (Setting the objectives and project scope)}

Preparation phase is followed by initiation stage; one of three institutions takes the lead to initiate the collaboration and set up its goal in the future. There are two main objectives of the triple helix trilateral collaboration, namely technology transfers, new business spin-off, and innovative area development. Based on reviews and analyses of all three sectors' performance in Indonesia (Table 1), the cooperation will focus on technology transfers from university to industry and new business development. Technology transfers will stimulate the university and academia to produce innovative products for telecommunication industry based on the need of industry and consumer. On the other hand, new business development is the impact of telecommunication industry growth through software and hardware generation to support the existing companies.

Triple helix model of collaboration expects the university to act as the leading sector among three institutions. However, the university's performance on research and international publication (table 1) shows that university lacks strength to lead the collaboration; their position can be replaced by the government initially. The government facilitates other two sectors to collaborate together to develop Indonesian telecommunication industry.

Some institutions which are invited to organize the collaboration can be derived from the existing telecommunication companies (Table 2) and the university which has electronics and information technology departments. In addition, university which will be invited to join the collaboration should be based on their researchers' performance and laboratory resources (Table 3). Based on the analyses of scientific publication and number of patents, the government has to allocate more budgets for the development of infrastructure and laboratory facilities to improve the research quality and its innovative products. 
Table 2: Product and production capacity of Indonesian telecommunication companies

\begin{tabular}{|c|c|c|}
\hline Company & Product & $\begin{array}{l}\text { Annual pro- } \\
\text { duction ca- } \\
\text { pacity }\end{array}$ \\
\hline PT. Hartono Istana Teknologi & Polytron & 500,000 \\
\hline PT. Aries Indo Global & Evercoss & $1,200,000$ \\
\hline PT. Arga Mas Lestari & Advan & 500,000 \\
\hline PT. Tera Data Indonusa & Axioo & 300,000 \\
\hline PT. Maju Express Indonesia & Mito & 625,000 \\
\hline PT. Sinar Bintang Nusantara & Gosco & 400,000 \\
\hline PT. Supertone & SPC & 600,000 \\
\hline PT. Zhou International & AsiaFone & 600,000 \\
\hline PT. Samsung Indonesia & Samsung & $14,400,000$ \\
\hline PT. Oppo Indonesia Electronics & Oppo & $1,200,000$ \\
\hline $\begin{array}{l}\text { PT. Hair Electrical Appliances Indo- } \\
\text { nesia }\end{array}$ & Haier & $1,000,000$ \\
\hline $\begin{array}{l}\text { PT. Huawei (PT. Panggung Electri- } \\
\text { cal Citra Buana) }\end{array}$ & Huawei & 500,000 \\
\hline PT. Smartfren Telecom & Smartfren & 350,000 \\
\hline $\begin{array}{c}\text { PT. ZTE (PT. Panggung Electrical } \\
\text { Citra Buana) }\end{array}$ & Bolt & 350,000 \\
\hline $\begin{array}{l}\text { PT. Tridarma Kencana (PT. Lenovo } \\
\text { Indonesia) }\end{array}$ & Lenovo & 350,000 \\
\hline $\begin{array}{l}\text { PT. Satnusa Persada \& PT. Tata } \\
\text { Sarana Mandiri }\end{array}$ & Ivo & 250,000 \\
\hline
\end{tabular}

Table 3: Rank of Indonesian university based on National Accreditation (NA), world university rankings (QS), Time Higher Education (THE), and Webometrics ranking of World Universities (WM) 2015/2016

\begin{tabular}{ccccc}
\hline University & NA & QS & THE & WM \\
\hline University of Indonesia & A & 358 & $601+$ & 909 \\
Institute of Technology Ban- & A & $431+$ & & 819 \\
$\begin{array}{c}\text { dung } \\
\text { Gadjah Mada University }\end{array}$ & A & $551+$ & 781 \\
Airlangga University & A & $700+$ & 1,440 \\
Bogor Agricultural University & A & $700+$ & 1,554 \\
Diponegoro University & A & $700+$ & 1,528 \\
Institut Teknologi Sepuluh & A & $700+$ & 1,887 \\
$\begin{array}{c}\text { Nopember } \\
\text { Muhammadiyah University of }\end{array}$ & B & $700+$ & 3,547 \\
$\begin{array}{c}\text { Surakarta } \\
\text { Brawijaya University }\end{array}$ & A & $700+$ & 1,517 \\
\hline
\end{tabular}

Source: www.ban-pt-universitas.com

\subsubsection{Implementation}

Most of managers invest a lot of their time on setting up their goal and strategy to achieve it, but implementing and realizing it are really important [15]. In the implementation phase, each institution sends a representative to collaborate. The representatives must have a strong desire and motivation to develop and improve Indonesian telecommunication industry. During the process, obstacles are expected to be resolved through good cooperation among three sectors. The industry provides information about condition of telecommunication market in Indonesia and practical experience in assembling and trading mobile phones in Indonesia. Reciprocally, the role of universities is to conduct high-quality research and produce innovative products as needed by consumers. Mutually, the government acts to assist the laboratory facilities development in universities, facilitate the patent application, and give some incentives for both industry and university.

\subsubsection{Evaluation}

Evaluation is an assessment of project or program performance focus on its achievement and effectiveness as an integral part of strategic planning [16]. Triple helix on telecommunication industry development in Indonesia will be implemented based on some indicators resulting from the trilateral cooperation among university, industry, and government. In the early stages of collaboration, its indicator can be observed from researchers' ability to conduct high-quality research and produce innovative products in accordance with the market appeals. At this stage, the output is focused on technology transfer from the academia to industry by creating innovative products that can be accepted by the consumers. During the creation of innovative product, government assists researcher and industry to pursue the patent or copyright, so it will give those benefits in the future. This success story is expected to inspire other researchers to be more productive.

The next step is to create the new telecommunication industry and firm. It can be focused on the manufacturer of components for mobile phones and software development. Finally, the collaboration among university, industry, and government enormously fosters Indonesian telecommunication industry to use more local contents and resources, be more productive, and support the economic growth in advance.

Table 4: Indicators of achievement in each phase

\begin{tabular}{cc}
\hline Phase & Indicator \\
\hline Phase 1 & Improving the quality of academia and laboratory facil- \\
& ities \\
& Technology transfers \\
& Number of patents \\
& Customer satisfaction with the products \\
Thase 2 & Technology transfer \\
& Number of patents \\
& Customer satisfaction with the products \\
Business spin-off
\end{tabular}

\section{Discussion}

The development of Indonesian telecommunications industry can be improved through the collaboration among government, industry, and university. It should be implemented from four stages, namely preparation, initiation, implementation, and evaluation. Reviewing and analyzing the current condition of each institution in collaboration are the first steps in preparation stage. Second stage, initiation, aims to find out the priority of each institution within relation in the collaboration according to the analysis. Then it should be ready to start working, practicing, and achieving the developmental plan of improving collaboration from previous stage accordingly. Evaluation of results and efforts aims to determine and fix the significance, value, or its condition with the indicators at the conclusion of collaboration model.

Based on the analysis of university's performance on scientific publication and number of patents, it can be concluded that there is a lack of university's readiness to participate in the innovative research production, particularly in telecommunication industry. This conclusion in line with Bappenas [17] report which revealed that Science Techno Park (STP), as one form of triple helix implementation in Indonesia, unable to achieve optimal outcome to improve the number of intellectual property (IP) and new innovative products in Indonesia.

The government needs to improve quality of human resource and laboratory facility, encourage high-quality research, and produce innovative products as required by consumers. The government might improve quality of human resource by providing scholarships to study abroad, particularly to countries with practical experience in the development of a knowledge-based industry. Previous studies exposed that educational achievement is a primary determining factor of nation's global competitiveness $[18,19]$. Educational attainment combine with the direct experience in the develop countries will further stimulate students from Indonesia to learn how to implement knowledge-based economy.

Moreover, industries should support the university's ability to create marketable products by providing input based on their em- 
pirical experience on product development. Inputs from industry will give more accurate information for the academia to conduct high-quality research and produce new innovative products. Through open communication among industry, university, and government, the entire technology transfer industry can mutually benefit all the institutions [20].

\section{Conclusion}

The triple helix model of innovation appeals for extensive collaboration among university, industry, and government. This model has become salient in the development of Indonesian telecommunication industry. Readiness of Indonesia to implement knowledge-based economy development needs to be improved because of the research institutions' capability to produce innovative products needs further encouragement, the number of domestic telecommunication industries is not adequate, and government regulations do not fully support the development of the telecommunication industry in the country. It might be improved through human resource development, research facility enhancement, and by encouraging industry and governments' participation in basic research and education.

\section{References}

[1] Global Media Intelligence Report, 2015. Smartphone users and penetration in Asia-PACIFIC BY Country, 2014-2019.

[2] Etzkowitz, H., Ranga, M., \& Dzisah, J., 2012. Whither the university? The novum trivium and the transition from industrial to knowledge society. Social science information, 51 (2), 143-164. DOI: $10.1177 / 0539018412437099$.

[3] Leydesdorff, L., 2012. The Triple Helix of University-IndustryGovernment Relations.

[4] Viale, R. \& Etzkowitz, H., 2010. The capitalization of knowledge: a triple helix of university-industry-government. pp 1-30. Edward Elgar Publishing Limited. UK

[5] Farinha, L. \& Ferreira, J.J., 2013. Triangulation of the triple helix: a conceptual framework.

[6] Lucy, Y.L., 2006. Beyond the Triple Helix: Examining the Implementation Process of Knowledge-based Innovation in the North East of England. Thesis of Newcastle University Business School.

[7] Etzkowitz, H., 2011. The triple helix of university-industrygovernment implications for policy and evaluation. Working paper 2002-11.

[8] Ivanova, I.A. \& Leydesdorff, L., 2012. Rotational Symmetry and the Transformation of Innovation Systems in a Triple Helix of University-Industry-Government Relations. Technological Forecasting \& Social Change (in press).

[9] Ranga, M. \& Etzkowitz, H., 2013. Triple helix systems: an analytical framework for innovation policy and practice in the knowledge society. Industry \& Higher Education. (27 (3). 237-262. doi: 10.5367/ihe.2013.0165.

[10] Etzkowitz, H., 2007. University-Industry-Government: The triple helix model of innovation.

[11] Casas, R., De Gortari, R., and M. Santos, M., 2000. The building of knowledge spaces in Mexico: a regional approach to networking. Research Policy, 29 (2), 225-241.

[12] Yegorov, I. \& Ranga, M., 2014. Innovation, politics and tanks: the emergence of a Triple Helix system in Ukraine and the influence of EU cooperation on its development. Int. J. Transition and Innovation systems.

[13] Young, M.K., 2013. Industry, academia, and government collaboration: a game changer for US economic future. Business Horizon Quarterly

[14] Plaisier, H., 2010. Triple helix cooperation in the Rotterdam region. Thesis. Erasmus Universiteit Rotterdam

[15] Brinkschröder, N. 2014. Strategy implementation: Key factors, challenges and solutions (Bachelor's thesis, University of Twente)

[16] WHO. 2013. WHO Evaluation practice handbook. Switzerland.

[17] Bappenas. 2015. Studi pengembangan techno park di Indonesia: survey terhadap 10 embrio techno park di Indonesia. Bappenas, Jakarta.

[18] Acemoglu, D., Robinson, J.A., 2012. Why Nations Fail: The Origins of Power, Prosperity, and Poverty. Crown Publishing Group, New York, NY.
[19] Organization for Economic Co-operation and Development, 2012. Education at a Glance 2012: OECD indicators. OECD Publishing, Paris

[20] Barrow, A., Batchelor, L. R., Alex Breger, J. D., Duval-Couetil, N., Scott, L., Skinner, J., \& Phyl Speser, J. D. 2014. Managing Student Intellectual Property Issues at Institutions of Higher Education: An AUTM Primer. Retrieved November 14, 2017 from https://www.autm.net/AUTMMain/media/ThirdEditionPDFs/V2/T TP_Manual_3rd_Edition_Volume2_StudentIP.pdf. 